\title{
Comparative Assessment of Phytochemical Constituents of Raphia Vinifera P.Beauv and Raphia Hookeri G. Mann \& H. Wendl.
}

\author{
Felix Okponanabofa Youkparigha ${ }^{1^{*}}$, Ngozy Maureen Uzoekwe ${ }^{2}$, Preye Mercy Ogumo ${ }^{1}$ \\ ${ }^{1}$ Department of Biological Sciences, Faculty of Science, Niger Delta University, Wilberforce Island, Bayelsa \\ State, Nigeria \\ ${ }^{2}$ Department of Physical Sciences, Faculty of Science, Benson Idahosa University, Benin City, Nigeria
}

*Corresponding Author: Felix Okponanabofa Youkparigha, Department of Biological Sciences, Faculty of Science, Niger Delta University, Wilberforce Island, Bayelsa State, Nigeria

\begin{abstract}
This study involved the comparative analysis of the phytochemical constituents of the fruits ofRaphia vinifera and Raphia hookeri. The fruits were obtained from the Wilberforce Island, Bayelsa State, Nigeria. The fruits were processed and pulp obtained and analyzed for Alkaloids, Saponins, Flavonoids, Glycosides, and Tannins concentration following standard methods for the quantitiave determination of phytochemicals in plants. Results showed that Alkaloid, Saponin, Tannins, Flavonoids and Glycosides content were $21.58 \pm 0.08 \%, 5.30 \pm 0.14 \%, 7.23 \pm 0.27 \%, 7.09 \pm 0.24 \%$ and $0.08 \pm 0.00 \%$, respectively for Raphia hookeri, and $22.00 \pm 0.34 \%, 0.35 \pm 0.49 \%, 4.61 \pm 0.00 \%, 1.99 \pm 0.04 \%$ and $0.10 \pm 0.00 \%$, respectively for Raphia vinifera. There were significant variations $(p<0.05)$ between Raphia hookeri and Raphia vinifera with respect to flavonoids, saponin, and tannins. Also no significant variation $(p>0.05)$ exist in the alkaloid content of both plants (Raphia hookeri and Raphia vinifera). The study showed that Raphia hookeri possess significantly higher phytochemicals compared to Raphia vinifera for most of the parameters studied. This suggests that Raphia hookeri may confer more potent pharmacological properties than Raphia vinifera. Based on the finding of this preliminary investigation into the medicinal properties of Raphia hookeri and Raphia vinifera, there is the need for research to focus on the specific medicinal properties of the fruit pulps.
\end{abstract}

Keywords: Medicinal plant, Phytochemicals, Raphia hookeri and Raphia vinifera

\section{INTRODUCTION}

Several palm trees belonging to different genera including Elaeis, Borassus, Raphia, Eremospatha, Phoenix, Calamus, Podococcus, Hyphaene, Ancistrophyllum, Sclerosperma and Oncocalimuns are found in Nigeria (Obahiagbon, 2009; Okon and Okorji, 2014; Oluwaniyi et al., 2014; Oduah and Ohimain, 2015). The genus Raphia is one of the largest palm that is African, especially in West Africa. In addition, Raphia (Raphia sp) palms are among the most diverse and geographically wide spread palms (Kigigha et al., 2015a). Raphia palm are frequently spelled as "Raffia" (Oduah and Ohimain, 2015; Ohimain et al., 2012, 2015) or "Raphia" (Obahiagbon and Osagie, 2007; Obahiagbon, 2009) in literatures.

Raphia palm is one of the palms that is found in the wild in the freshwater zone in many areas in the Niger Delta region of Nigeria (Oduah and Ohimain, 2015). According to Oduah and Ohimain (2015), raphia palm is used for building construction, production of brooms, baskets, ropes and construction of fish, crab and turtle traps by the indigenous people of areas that they are found in the Niger Delta. The authors further reported that palm wine and locally fermented gin are produced from the Raphia palm.

There are several species of Raphia palm, but some the commonest are Raphia vinifera and Raphiahookeri. Raphia hookeri is found from Gambia through the Guinea forest zone of West Africa to Cameroon, Gabon and Congo and possibly to DR Congo and Angola (Brink, 2011). Raphia hookeri have been widely reported in fresh water zone in the Niger Delta region of Nigeria. Furthermore, Raphia vinifera is distributed from Benin eastwards to DR Congo, and it has been grown in Nigeria and Cameroon (Jiofack Tafokou, 2011). Raphia hookeri and Raphia vinifera are the 
most commonly studied Raphia palms (Karamoko et al., 2012; Ohimain et al., 2012; Oduah and Ohimain, 2015; Obahiagbon, 2009; Obahiagbon and Osagie, 2007).

Several studies have been carried out with regard to Raphia palm in the Niger Delta including the effect of aqueous root extracts of Raphia hookeri inincreasing metabolic clearance (MCR) rate of ethanol in rabbits (Akpan and Usoh, 2004), the use of mesocarp of Raphia palm to stupefy and catch fishes (Ohimain et al., 2015), physicochemical characteristics and productivity of Raphia palm (Oduah and Ohimain, 2015).

The search for plants with medicinal properties has increased. Authors have attributed the pharmacological properties of medicinal plants to their bioactive and phytochemical constituents (Epidi et al., 2016a,b; Izah and Aseibai, 2018; Izah et al., 2018a -e; Izah, 2018; Kigigha et al., $2018 \mathrm{a}, \mathrm{b})$. As such, the presence of phytochemicals in a plant provides preliminary information about its therapeutic properties. To this effects, authors have studied the phytochemical constituents of the pulp and seed of Raphia hookeri (Ogbuagu, 2008), leaf and epicarp of Raphia hookeri (Abimbola et al., 2018) and fruits of Raphia hookeri and Raphia farinifera (Oluwaniyi et al., 2014). This present study is aimed at a comparative assessment of the phytochemical constituents of Raphia vinifera and Raphia hookeri.

\section{MATERIALS AND METHODS}

\subsection{Plant Collection and Identification}

The fruits of Raphia vinifera and Raphia hookeri were obtained from the wild in freshwater forest zone in Wilberforce Island, Nigeria. The Raphia palms (Raphia vinifera and Raphia hookeri) were identified by a certified taxonomist. The fruits were processed and the pulpsobtained were dried prior to quantitative photochemical determination.

\subsection{Phytochemical Analysis}

The quantitative phytochemical analysis was carried out based on well-established standard procedures in literature viz: alkaloids (Harborne, 1973), flavonoids (Boham and Kocipal-Abyazan, 1994), tannins (Oluwaniyi et al., 2014), Saponins were determined according to the method described by Okwu (2005) and cyanogenic glycoside by Alkaline Titration Method (AOAC, 1984).

\subsection{Statistical Analysis}

SPSS version 20 was used for the statistical analysis. Data were expressed as mean \pm standard deviation; Student t-test was carried out at $\mathrm{p}=0.05$ to show significant variation between Raphia hookeriand Raphia vinifera with respect to their phytochemical contents (flavonoids, saponins, glycosides, alkaloids and tannins).

\section{RESULT AND DISCUSSION}

Table 1 presents the phytochemical contents of the pulp of Raphia hookeriand Raphia vinifera fruits. The saponins contents in Raphia hookeriand Raphia vinifera were $5.30 \pm 0.14 \%$ and $0.35 \pm 0.49 \%$, respectively. There were significant variations $(\mathrm{p}<0.05)$ in phytochemical contents between Raphia hookeriand Raphia vinifera. In this study the concentration of saponins were higher in the Raphia hookeri compared to Raphia vinifera. This suggests that Raphia hookerimayhave a superior effect in possible pharmacological properties the plant may confer. Basically, saponins have been reported to have expectorant and cough suppressant potentials (Kigigha et al., 2015b; Okwu, 2005; Osuntokun and Oluwafoise, 2015; Epidi et al., 2016a, b). Authors have reported saponins contents of $0.36 \%$ and $0.23 \%$ in pulp and seed of Raphia hookeri (Ogbuagu, 2008). Oluwaniyi et al. (2014) reported 0.87\%, $2.25 \%$ and $0.79 \%$ of saponins in shell, pulp and seed of Raphia hookeri. In Raphia hookeri, saponins have been reported in leaf and epicarp (Abimbola et al., 2018) and aqueous root extract (Akpan and Usoh, 2004)

The tannins content in Raphia hookeri and Raphia vinifera were $7.23 \pm 0.27 \%$ and $4.61 \pm 0.00 \%$, respectively. There is significantly higher value in Raphia hookeri than in Raphia vinifera. Oluwaniyi et al. (2014) reported $0.00 \%, 0.60 \%$ and $0.00 \%$ of tannins in shell, pulp and seed of Raphia hookeri. Akpan and Usoh (2004) reported the presence of tannins in aqueous root extract of Raphia hookeri. Like many other phytochemical constituents, tannins play essential role in healing wounds, varicose 
ulcers, hemorrhoids, frostbites and burns (Okwu and Okwu, 2004; Doherty et al., 2010; Kigigha et al., 2015b; Osuntokun and Oluwafoise, 2015; Youkparigha et al., 2019a,b). In addition, tannins have anti-inflammatory and anti-diuretic activity.

The flavonoids content in Raphia hookeri and Raphia vinifera were $7.09 \pm 0.24 \%$ and $1.99 \pm 0.04 \%$, respectively. There is significantly higher value in Raphia hookeri than in Raphia vinifera. Oluwaniyi et al. (2014) reported $1.28 \%, 0.00 \%$ and $0.00 \%$ of flavonoids in shell, pulp and seed of Raphia hookeri. Ogbuagu (2008) reported flavonoids level of $0.40 \%$ and $0.24 \%$ in pulp and seed of Raphia hookeri. In Raphia hookeri, flavonoids have been reported in leaf and epicarp (Abimbola et al., 2018) and aqueous root extract (Akpan and Usoh, 2004). Like saponins and tannins, the variation observed in the flavonoids concentrations in this study compared to other previous studies may be associated with the plant part used, their maturity statusand the characteristics of the environment in which the palm was collected (Izah, 2018). Flavonoids are essential in treating tumours especially in the early stage of development. In addition, authors have widely reported antioxidant, anticarcinogenic and antimicrobial potentials of flavonoids (Kigigha et al., 2015b; Youkparigha et al., 2019a,b; Osuntokun and Oluwafoise, 2015).

Table1. Phytochemical contents of the pulp of Raphia hookeriand Raphia vinifera fruits

\begin{tabular}{|c|c|c|c|c|}
\hline \multirow{2}{*}{ Phytochemicals } & Mean \pm Standard deviation & Mean \pm Standard deviation & \multirow{2}{*}{ t-value } & \multirow{2}{*}{-value } \\
\cline { 2 - 4 } & Raphia hookeri & Raphia vinifera & & \\
\hline Alkaloid, \% & $21.58 \pm 0.08$ & $22.00 \pm 0.34$ & -1.698 & 0.232 \\
\hline Saponin, \% & $5.30 \pm 0.14$ & $0.35 \pm 0.49$ & 13.599 & 0.005 \\
\hline Tannins, \% & $7.23 \pm 0.27$ & $4.61 \pm 0.00$ & 13.782 & 0.005 \\
\hline Flavonoids, \% & $7.09 \pm 0.24$ & $1.99 \pm 0.04$ & 29.544 & 0.001 \\
\hline Glycoside, \% & $0.08 \pm 0.000$ & $0.10 \pm 0.000$ & NA & NA \\
\hline
\end{tabular}

NA=Not applicable

The alkaloid level in Raphia hookeri and Raphia vinifera were $21.58 \pm 0.08 \%$ and $22.00 \pm 0.34 \%$, respectively, being not significantly different $(\mathrm{P}>0.05)$ between Raphia hookeri and Raphia vinifera. The values recorded in this study are far higher than the values of $0.5 \%$ and $0.35 \%$ in fruit pulp and seed of Raphia hookeri by Ogbuagu(2008). Alkaloids have been reported in leaf and epicarp (Abimbola et al., 2018) and aqueous root extract ofRaphia hookeri (Akpan and Usoh, 2004). Alkaloids from medicinal plants have been reported to confer analgesic, antispasmodic and bactericidal activities (Epidi et al., 2016a, b; Doherty et al., 2010; Osuntokun and Oluwafoise, 2015).

The glycoside concentration in Raphia hookeri and Raphia vinifera were $0.08 \pm 0.00 \%$ and $0.10 \pm 0.00 \%$, respectively. The glycoside content in the Raphia vinifera wasslightly higher than that of Raphia hookeri. Akpan and Usoh (2004) reported the presence of cardiac glycoside and cyanogenic glycoside in aqueous root extract of Raphia hookeri. Basically, glycosides possess analgesic, antipyretic, and anti-inflammatory activities (Youkparigha et al., 2019a,b). In addition, some types of glycosides have been reported to play defensive roles in plants against pathogens(Aberoumand, 2012).

\section{CONCLUSION}

The study focused on the comparative analysis of phytochemical constituents of fruit pulp of Raphia vinifera and Raphia hookeri from Wilberforce Island, Nigeria. The study showed that Raphia hookeri possessed significantly higher quantities of phytochemicals compared to Raphia vinifera. An indication that Raphia hookeri may confer more potent therapeutic properties than Raphia vinifera.

\section{REFERENCES}

[1] Aberoumand, A. (2012). Screening of Phytochemical Compounds and Toxic Proteinaceous Protease Inhibitor in Some Lesser-Known Food Based Plants and Their Effects and Potential Applications in Food. International Journal of Food Science and Nutrition Engineering, 2(2), 1-5.

[2] Abimbola, O.P., Oluwasogo, D.A., \& Adejumoke, I.A. (2018). Phytochemical Analysis and Antioxidant Potential of Raphia hookeri leaf and Epicarp. Orient. J. Chem., 34(6), 2742-2746.

[3] Akpan, E.J., \& Usoh, I.F. (2004). Phytochemical screening and effect of aqueous root extract of Raphia hookeri (raffia palm) on metabolic clearance rate of ethanol in rabbits. Biokemistri, 16(1), 37-42. 
[4] AOAC (1984). Official Methods of Analysis. Association of Official Analytical Chemists. 14th Edition, AOAC, Arlington.

[5] Boham, B.A. \& Kocipal-Abyazan, R. (1994). Flavonoids and condensed tannins from leaves of Vaccinium vaticulatum and V. calycinium. Pacific Science, 48, 458-463.

[6] Brink, M. (2011). Raphia hookeriG.Mann\& H.Wendl. [Internet] Record from PROTA4U. Brink, M. \& Achigan-Dako, E.G. (Editors). PROTA (Plant Resources of Tropical Africa / Ressources végétales de l'Afrique tropicale), Wageningen, Netherlands. $<$ http://www.prota4u.org/search.asp $>$.

[7] Doherty, V.F., Olaniran, O.O., \& Kanife, U.C. (2010). Antimicrobial activities of Aframomum melegueta (Alligator pepper). International Journal of Biology, 2(2), 126-131.

[8] Epidi, J.O., Izah, S.C., \& Ohimain, E.I. (2016a). Antibacterial and synergistic efficacy of extracts of Alstonia boonei tissues. British Journal of Applied Science, 1(1), 21 - 26.

[9] Epidi, J.O., Izah, S.C., Ohimain, E.I., \& Epidi, T.T. (2016b). Antibacterial and synergistic potency of tissues of Vitex grandifolia. Biotechnological Research, 2(2), 69-76.

[10] Harborne, J.B. (1973). Phytochemical methods- A Guide to modern Techniques of plant analysis. Chapman and Hall, London. 278pp.

[11] Izah, S.C. (2018). Some determinant factors of antimicrobial susceptibility pattern of plant extracts. Research and Review Insight, 2(3), 1-4

[12] Izah, S.C., \& Aseibai, E.R. (2018). Antibacterial and Synergistic activities of methanolic leaf extract of Lemon grass (Cymbopogon citratus) and rhizome of Ginger (Zingiber officinale) against Escherichia coli, Staphylococcus aureus and Bacillus species. ACTA Microbiology, 1(6), 26-30.

[13] Izah, S.C., Uhunmwangho, E.J., \& Dunga, K.E. (2018a). Studies on the synergistic effectiveness of methanolic extract of leaves and roots of Carica papaya L. (papaya) against some bacteria pathogens. International Journal of Complementary and Alternative Medicine, 11(6), 375-378.

[14] Izah, S.C., Uhunmwangho, E.J., \& Eledo, B.O. (2018b). Medicinal potentials of Buchholzia coriacea (wonderful kola). Medicinal Plant Research, 8(5), 27-43.

[15] Izah, S.C., Uhunmwangho, E.J., \& Etim, N.G. (2018c). Antibacterial and synergistic potency of methanolic leaf extracts of Vernonia amygdalina L. and Ocimum gratissimum L. Journal of Basic Pharmacology and Toxicology, 2(1), 8-12

[16] Izah, S.C., Uhunmwangho, E.J., Dunga, K.E., \& Kigigha, L.T. (2018d). Synergy of methanolic leave and stem-back extract of Anacardium occidentale 1. (cashew) against some enteric and superficial bacteria pathogens. MOJ Toxicology, 4(3), 209-211.

[17] Izah, S.C., Zige, D.V., Alagoa, K.J., Uhunmwangho, E.J., \& Iyamu, A.O. (2018e). Antibacterial Efficacy of Aqueous Extract of Myristica fragrans (Common Nutmeg). EC Pharmacology and Toxicology, 6(4), 291-295.

[18] Jiofack Tafokou, R.B. (2011). Raphia vinifera P.Beauv. [Internet] Record from PROTA4U. Brink, M. \& Achigan-Dako, E.G. (Editors). PROTA (Plant Resources of Tropical Africa / Ressources végétales de l'Afrique tropicale), Wageningen, Netherlands. <http://www.prota4u.org

[19] Karamoko, D., Djeni, N.T., N'guessan, K.F., Bouatenin, K.M.J-P., \& Dje, K.M. (2012). The biochemical and microbiological quality of palm wine samples produced at different periods during tapping and changes which occurred during their storage. Food Control, 26, $504-511$.

[20] Kigigha, L.T., Izah, S.C., \& Okitah, L.B. (2015a). Antibacterial activity of palm wine against Pseudomonas, Bacillus, Staphylococcus, Escherichia, and Proteus spp. Point Journal of Botany and Microbiology Research, 2(1), 046-052.

[21] Kigigha, L.T., Izah, S.C., \& Ehizibue, M. (2015b). Activities of Aframomum melegueta Seed Against Escherichia coli, S. aureus and Bacillus species. Point Journal of Botany and Microbiology Research, $1(2), 23-29$.

[22] Kigigha, L.T., Izah, S.C., \& Uhunmwangho, E.J. (2018a). Assessment of hot water and ethanolic leaf extracts of Cymbopogon citratus Stapf (Lemon grass) against selected bacteria pathogens. Annals of Microbiology and Infectious Diseases, 1(3), 1- 5.

[23] Kigigha, L.T., Selekere, R.E., \& Izah, S.C. (2018b). Antibacterial and synergistic efficacy of acetone extracts of Garcinia kola (Bitter kola) and Buchholzia coriacea (Wonderful kola). Journal of Basic Pharmacology and Toxicology, 2(1), 13-17.

[24] Obahiagbon, F.I. (2009). A review of the origin, morphology, cultivation, economic products, health and physiological implications of raphia palm. Africa Journal of Food Science 3 (13): 447 - 453

[25] Obahiagbon, F.I., \& Osagie, A.U. (2007). Sugar and macrominerals composition of sap produced by Raphia hookeri palms. Africa Journal of Biotechnology, 6 (6), 744 - 750 
[26] Oduah, A.A., \& Ohimain, E.I. (2015). Ethnobotany of raffia palm (Raphia hookeri), productivity assessment and characterization of raffia palm oil from the Niger Delta, Nigeria. Res. J. Phytomed., 1(1), 33- 38.

[27] Ogbuagu, M.N. (2008). Vitamins, phytochemicals and toxic elements in the pulp and seed of raphia palm fruit (Raphia hookeri)Fruits, 2008, vol. 63, p. 297-302

[28] Ohimain, E. I. Tuwon, P. E., \& Ayibaebi, E. A. (2012). Traditional fermentation and distillation of raffia palm sap for the production of bioethanol in Bayelsa State, Nigeria. Journal of Technology Innovations in Renewable Energy, 1 (2), 131-141

[29] Ohimain, E.I., Inyang, I.R., \& Osai, G.U. (2015). The Effects of Raffia Palm Mesocarp on Haematological Parameters of Clarias gariepinus, a Common Niger Delta Wetland Fish. Annual Research \& Review in Biology, 8(1): 1-7.

[30] Okon, U.E., \& Okorji, E.C. (2014). Economic analysis of raphia palm (raphia spp.) wine production in Akwa Ibom state, Nigeria. Int. J. Agric. Crop Sci., 7(6), 347-352.

[31] Okwu, D.E. \& Okwu, M.E. (2004). Chemical composition of Spondias mombia Linn plant parts. Journal of Sustain Agricultural Environment, 6, 140-147.

[32] Okwu, D.E. (2005). Phytochemicals, Vitamins and Mineral contents of two Nigeria Medicinal Plants. International Journal of Molecular Medicine and Advance Sciences, 1 (4), 375-381

[33] Oluwaniyi, O.O., Odebunmi, E.O., \& Owolabi, C.O. (2014). Qualitative and quantitative evaluation of the phytochemicals of Raphia hookeri and Raphia farinifera fruits. Science Focus, 19 (1), 28 - 33.

[34] Osuntokun, O.T. \& Oluwafoise, B.O. (2015). Phytochemical screening of ten Nigerian medicinal plants. International Journal of Multidisplinary Research and Development, 2(4), 390-396.

[35] Youkparigha, F.O., Nyananyo, B.L., \& Oyedeji, A.A. (2019a). Evaluation of the Bioactive Compounds in Leaves and Stem-Bark of Piptadeniastrum Africanum (Hook.F.) Brenan (Family Fabaceae). International Journal of Medicinal Plants and Natural Products, 5(2), 1-7.

[36] Youkparigha, F.O., Nyananyo, B.L., \& Oyedeji, A.A. (2019b). Phytochemical and Anti-nutritional potentials of leaves and stem-bark of Cathormion altissimum (Hook.f.) Hutch. \& Dandy. Biotechnol Res., $5(2), 5-8$.

Citation: Felix Okponanabofa Youkparigha, et.al, "Comparative Assessment of Phytochemical Constituents of Raphia Vinifera P.Beauv and Raphia Hookeri G. Mann \& H. Wendl.”. International Journal of Advanced Research in Botany (IJARB), vol. 5, no. 4, pp. 10-14, 2019. DOI: http://dx.doi.org/10.20431/24554316.0504002 .

Copyright: () 2019 Authors. This is an open-access article distributed under the terms of the Creative Commons Attribution License, which permits unrestricted use, distribution, and reproduction in any medium, provided the original author and source are credited. 